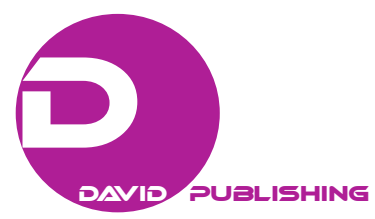

\title{
The Effects of Religion on the Immigration Process in the USA: An Experiment
}

\author{
Serap Gur \\ Louisiana State University, Louisiana, USA
}

\begin{abstract}
This paper seeks to present how people's attitudes change according to the religion of immigrants and how this affects the immigrants' citizenship process in the USA. In general, immigration is a controversial issue, for that reason people may conceal their real thoughts and have a tendency to give the socially accepted answers. For that reason, in this paper the list experiment method is used to get the real opinions of people. Results indicate that, people in fact conceal their real thoughts in response to direct survey questions. In addition, the results show that Americans are generally concerned about immigration. However, when it is compared to Muslim and Christian immigrants, people are more likely to support granting citizenship to a Christian immigrant compared to a Muslim immigrant. The other most important finding is that being against Muslim immigrants is considered more acceptable. In other words, people may feel pressure to say that they do not support Muslim immigration, for that reason when it is asked directly, some people (more than 10\%) automatically say that they are against Muslim immigrants compared to the findings in the list experiment.
\end{abstract}

Keywords: immigration, Muslim immigrants, Christian immigrants, list experiment, the USA

\section{Introduction}

While some people oppose to immigration, some are in favor of it. Unfortunately there is not an agreement about immigration and people have different thoughts about immigrants. On the one hand, some Americans argue that immigrants are hard working people and have strong family values. On the other hand, $72 \%$ of Americans say that immigrants do not integrate to the American culture and society; in fact, they change the American society (Public Religion Research Institute, 2011).

Moreover, the research on foreign relations shows that most people (60\%) believe that increasing immigration creates an important threat to the USA. Other research indicates that American people were concerned about the immigration before 9/11, but after 9/11 negative feelings about immigrants increased particularly because of terrorism threat (Fulton, 2002). A very high number of people argue that immigrants are a "burden to the country, taking jobs and housing and creating strains on the health care system" (PEW Report, 2006, p. 1). Some are also concerned about the cultural aspects like having different family values, different community lives, and immigrants' assimilation problems (PEW Report, 2006).

Americans display different attitudes towards different immigrant groups. People have more positive attitudes towards both Latin American and Asian immigrants. They believe that these immigrant groups have 
strong family values and they are hard working compared to other immigrants (PEW Report, 2006). However, attitudes towards Muslim immigrants are not the same.

Since September 11, negative feelings towards Muslims and Islam have increased. For instance, Cable News Network (CNN)/USA Today/Gallup Poll (2002) indicated that most Americans think that Muslims cannot adopt Western Values, or some of them believe that Islam is equal to violence (CNN.com, March 4, 2002). In addition, Council of American-Islamic Relations shows that many Americans thought that Islam creates and supports more violence than any other religion (CAIR, 2006). More specifically, some Americans believe that Arabs and Muslims from America must be deported and their entrance to the country must be banned. Particularly, some Americans oppose to Muslim immigrants, because of general security threat. For instance, Muslim immigrants say that if there is any small problem in their citizenship applications, they are certainly exposed to deportation, because they are Muslims (Cardwell, 2003). All of these negative attitudes affect Muslims in different ways - their lives, their loyalties to America (Alibeli \& Yaghi, 2012).

In the literature there are many studies that evaluate the causes of opposing and favoring views towards immigration. However, there is not much attention to general attitudes of people towards different immigrant groups (Muslim and Christian immigrants). Hence, in this study the role of religion in the immigration process is evaluated. Also, a comparison of direct survey questions and list experiment answers are used to learn the people' real feelings about immigration. The main research question of the paper is that do people' attitudes change depending on the religion of immigrants and do they conceal their real attitudes in a direct survey?

The paper proceeds as follows: The first section starts with a literature review and presents the general attitudes towards Muslim and Christian immigrants; Then, the main hypotheses, research design and analysis of the study are presented; and finally, the results and conclusion are discussed.

\section{Literature Review}

Many studies focus on cultural and ethnic issues and claim that there is a tension between native and immigrant populations (Bauer, Lofstrom, \& Zimmerman, 2000; Burns \& Gimpel, 2000; Chandler \& Tsai, 2001; Citrin et al. 1997; Dustmann \& Preston, 2007; Espenshade \& Hempstead, 1996; Fetzer, 2000; Gang et al., 2002; McLaren, 2003; Lahav, 2004; Xhaho, 2014). These studies emphasize the ideological and cultural differences in explaining attitudes towards immigrants. Moreover, many other studies focus on economy and argue that economical concerns shape people's feelings about immigrants (Kinder \& Sears, 1981; Sears, Lau, Tyler, \& Allen, 1980; Sears \& Funk, 1990).

The role of public on immigration and immigrants is also emphasized. First, governments pay attention to public and create new policies based on public preferences. For new policies, governments need to take support from public, for that reason public attitude towards immigration influences government's policies. Second, public also affect the immigrants' daily life and their success. It creates discrimination and prejudices in the society (Esses, Dovidio, \& Hodson, 2002).

In addition, in the literature three common reasons of immigration are explained. First one is refuge. People are forced to move from their countries, because of tyranny, persecution, poverty, violent regime changes and wars. The second main reason is education. Most of students come to get a better education and after completing their education they turn back to their country (Pipes \& Duran, 2002). The third main reason is 
the economic condition, particularly for better jobs and higher wages. In addition, poverty, injustice and armed conflict, natural disasters are also indicated as other reasons of immigration (Smith, 2006). Even though reasons for immigration are similar across people of different faith, there are differences in backgrounds and how they were received in the USA. Thus, it is also important to individually discuss the backgrounds of Muslim and Christian immigrants and show the differences between them.

\section{Who are Muslim Immigrants?}

The first Muslim immigration began in the 15th century with the slave trade. Fourteen percent to $20 \%$ of slaves of West Africans were Muslims. However, the voluntary migration of Muslims began at the end of the 19th century. Muslims from the Middle Eastern countries like Lebanon, Syria, Egypt, and Palestine started to come to the USA. Then in the post World War II era, Muslim immigration increased. Most of new immigrants were students and they came for education (Schaeffer, 2006). As of 2010, more than seven million Muslims live in different parts of the USA (Moore, 2010). According to Paw Report, 65\% of the Muslims came from outside of the USA. Only 35\% of them were born in the USA. Most of the Muslim immigrants came from Arabic countries, but also there are people from Pakistan and other South Asian countries. In general, they are younger than other populations (Pew Research Center, 2007). In addition, Muslim minority group is the most diverse group in the USA. They come from different nations; have different traditions, languages, and political beliefs (Barreto, Masuoka, \& Sanchez, 2008). As a result, there is not a unity between Muslims. Arabs constitute the majority, but all Muslims are not Arabs (Mehdi, 1996; Naber, 2000).

American public is more negative towards the Muslims than other minorities and ethnic groups because of the terrorist attacks of $9 / 11$ and the political conditions after this attack. These issues with the adverse media coverage about Islam and Muslims increased the general antipathy towards Muslims (Kalkan, Layman, \& Uslaner, 2006; Latif, 2013). Most Muslims agree that after 9/11, being Muslim in the USA became harder. One third of Muslims say that they experienced some verbal harassment or threat in their lives in the USA. More interestingly, $47 \%$ of the Muslims feel themselves first Muslims, and then American (Pew Research Center, 2007).

Most American Muslims believe that they are living under the war against their religion. According to the American Islamic Relations (CAIR) report, more than half of the American Muslims experienced bias and discriminations since 9/11. In general, American Muslims are in a disadvantaged position in every part of the life, and certainly all these negativities and discriminations alienated them from American politics and society (Ayers, 2007). In 2000 election they supported the Bush administration, but after $9 / 11$ they began to support the Democratic Party. Bush's new foreign policy strategy and especially war on Islam affected this changing support. Moreover, new security policies in domestic politics after 9/11 increased discriminatory actions towards Muslim people who have Middle Eastern background (Barreto \& Bozonelos, 2009).

\section{Who are Christian Immigrants?}

USA is the top destination for Christian immigrants. In 2010, the number of Christian immigrants reached to approximately 32 million in the USA (Rogers, 2012). According to the New Immigrant Survey (2003) two-thirds of new immigrants are Christian, $42 \%$ of them are Catholic, $4.2 \%$ are Orthodox and $18.6 \%$ are 
Protestant.

In the USA, post-1965 immigrants are mostly Christian and majority of newcomers are also Christians. According to Pew Research Center's 2012 report "Faith on the Move: The Religious Affiliation of International Migrants", "Nearly six-in-ten legal Christian immigrants come from Latin America and the Caribbean (an average of about 370,000 each year)" (Pew Research Center, 2012). There are also some Christian immigrants who come from sub-Saharan Africa. The number of Christian immigrants from Europe has been in decline; it was $15 \%$ in 1992, but it was about 9\% in 2012 (Pew Research Center, 2012). In addition, Christian immigrants come to the USA from other parts of the world such as El Salvador, Guatemala, the Dominican Republic, Jamaica, Ecuador and Brazil. Moreover, some Christians emigrate from religiously mixed countries like Korea, Vietnam, India and Lebanon, Poland, Russia (Warner, 2004). In general, it is argued that Christian immigrants are less violent and are more integrated to the American society compared to Muslim immigrants (White, 2010).

According to the Pew Research Report (2013), Latinos constitute the largest group of Christian immigrants and the amount of Latino Christian immigrants continues to grow. Latino Catholic immigrants are more likely to identify themselves with the Democratic Party; however, they are more conservative than American Catholics about abortion or same-sex marriage. They are more likely to attend worship at least biweekly (Pew Research Report, 2013).

\section{Hypotheses}

According to the Public Religion Research Institute (2011), almost two-thirds of Americans argue that immigrants do not integrate to the American culture because of differing family values, community lives, and religion. In addition, according to the Pew Report (2006) most Americans believe that immigrants are a "burden to the country, taking jobs and housing and creating strains on the health care system" (p. 1). Especially after 9/11, due to the fear of terrorism, people became more negative towards immigrants (Fulton, 2002). Also, according to Pew Research Center immigration survey (2013), only $46 \%$ of American supports immigration; in other words, more than half of Americans are against the immigration to the USA (Pew Research Center, 2013). Based on these arguments, the researcher argues that many Americans are likely to position against the immigration to the USA. However, in many occasions some people do not speak out their real thoughts about controversial issues, like immigration, race or same-sex marriage, which is called social desirability bias (Spector, 2004). For that reason, the researcher expects that some people in response to a direct survey question will conceal their real thoughts about general immigration. This leads the first hypothesis:

H1: People will conceal their real feelings and overstate their opposition for cutting off all immigration to the USA in response to a direct survey question.

Second, after 9/11, American public became more negative towards the Muslims than other minorities and ethnic groups. Kalkan and colleagues (2006) and Latif (2013) argued that the adverse media coverage about Islam and Muslims increased the general antipathy towards Muslims in the USA. For instance, Council of American-Islamic Relations report shows that many Americans think Islam creates and supports more violence than any other religion (CAIR, 2006). According to the Pew Report (2007), most Muslims agree that after 9/11, being Muslim in the USA became harder and one third of Muslims say that they experienced some verbal 
harassment or threat in their lives in the USA after 9/11. In addition, according to the American Civil Liberties Union (ACLU), "it is more difficult (sometimes impossible) for Muslims to gain naturalized US citizenship", because ACLU claims that "US Citizenship and Immigration Services routinely screens immigrants for national security concerns, blacklists Muslims and has delayed applications of thousands of legal US residents for years" (American Civil Liberties Union, 2013, p. 1). Based on all these arguments, the researcher proposes that people are less in favor of granting citizenship to Muslim immigrants as a result of terrorism threat and all these negative feelings about Muslims. In addition, by using list experiment it is possible to overcome the problem in a direct survey in which people may conceal their opposition for granting citizenship to a Muslim immigrant. This leads to the second hypothesis:

H2: People will conceal their opposition for granting citizenship to a legal Muslim immigrant in response to a direct survey question.

Third, as discussed above, people have different feelings and attitudes toward different immigrant groups. Particularly, there is a difference between the attitudes towards Muslim immigrants versus Christian immigrants and they are more supportive of Christian legal immigrants compared to Muslim immigrants. For instance, According to the Pew Research Center "How Americans Feel about Religious Groups" report (2014), Americans have very positive feelings for Catholics - they receive 62 on the feeling thermometer (ranging from 0 to 100 - where 0 represents the most negative rating and 100 the most positive rating). Moreover, Muslims receive only 33 on the feeling thermometer (lowest among all religious affiliations). In addition, White (2010) argued that Christian immigrants are less violent and more integrated than Muslim immigrants. As a result of these arguments and the positive feelings toward Christian immigrants, people may be more supportive to grant citizenship to Christian immigrants compared to Muslim immigrants. Nevertheless, because of the general concern about immigration and general thoughts about immigrants - they are seen as a "burden to the country, taking jobs and housing and creating strains on the health care system (Pew Report 2006) - the author expects that in response to direct survey question, people will conceal their opposition for granting citizenship to also a Christian immigrant. This creates the third hypothesis:

H3: People will conceal their opposition for granting citizenship to a legal Christian immigrant in response to a direct survey question.

\section{Data and Methodology}

To test these hypotheses an experimental data from the Time Sharing Experiments for the Social Sciences (TESS) is used. The data set comes from the study of "Perceptions of Islam, Migration and Citizenship in the USA: A List Experiment" (Creighton, 2010).

People may not speak out their real thoughts regarding controversial issues like immigration (Spector, 2004). Therefore, a list experiment method is used in this study. The advantage of list experiment is that, people do not need to reveal their real opinion on any controversial issue. Hence, the list experiment is more successful to indicate the real opinions about controversial issues like race, immigration, same-sex marriage or gay-lesbian rights (Hubbard, Casper, \& Lessler, 1989). In a list experiment, participants are divided into a control group and a test group. In a control group, participants get a list of items and are asked to indicate how many of them apply, but they do not need say which one or ones. In a test group, people get the same list of items with an 
extra item. Again they report how many of them apply to them. As a result, the difference between the mean number of items reported by respondents in the control group and the mean number of items reported by respondents in the test group is "attributable to the presence of the additional item, plus sampling error; subtracting the control mean from the test condition mean and multiplying by 100 provides an estimate of the percent to whom the test item applies" (Zigerell, 2011, p. 553).

\section{Design}

In this experiment, sample was randomly divided into four groups-one control and three treatment groups for a total of seven questions. In the control group participants were asked about the importance of three relatively randomly ordered non-controversial issues. They were asked to tell how many of them they oppose, just the total number they were opposed but not asked to tell which ones. In each treatment group, participants were asked about the importance of four items, three are the same non-controversial topics and one controversial question that were randomly ordered. The difference in the mean number of items between the treatment and control group is attributable to the sampling error and the fourth controversial question.

The control group was first directed a list of questions and then individuals are directly asked about their opposition to the two types of potential citizens (Muslims and Christians) and immigration in general. Each treatment group was directed the same list of questions with a fourth item based on one of the three obtrusive questions from the control. Each of these lists is randomized to prevent bias.

Table 1

Total Sample

\begin{tabular}{lccc}
\hline Sample & Frequency & Percent $(\%)$ & Cum. \\
\hline Control & 813 & 24.71 & 24.71 \\
Treatment 1 & 832 & 25.29 & 50.00 \\
Treatment 2 & 805 & 24.47 & 74.47 \\
Treatment 3 & 840 & 25.53 & 100.00 \\
Total & 3,290 & 100.00 & \\
\hline
\end{tabular}

\section{Sample}

Creighton (2010) determined the sample according to a previous study prepared by TESS in 2007 about opposition to immigration. The previous study (Janus, 2007) provided the mean and standard deviation of the number of respondents opposed to immigration $(2.42,0.81)$ and the control $(2.19,0.92)$. Creighton (2010) used these values to indicate the sample size needed for an alpha of 0.01 and a power of 0.95 for control groups and he finds that it is needed $448 * 4=1.792$ sample sizes for control groups. Then for testing control group and treatment group, Creighton (2010) increased the power and alpha level and found that he needs a total sample size of 3,252 with 813 respondents in the control and each of the three treatment groups. Following these sample requirements, the sample size and percentage information for the one control and three treatment groups of the present study are presented in Table 1.

\section{Analysis and Results}

First, a regression analysis is performed to show which factors influence the opposition to general 
immigration and to show whether there are differences in factors that affect opposition to Muslim immigrants versus Christian immigrants (see Table 2).

Table 2

Determinants of Opposition to Migration, Muslim and Christian Immigrants

\begin{tabular}{|c|c|c|c|c|c|c|c|c|c|}
\hline & $\begin{array}{l}\text { Model } 1 \\
\text { (General } \\
\text { Immigration) }\end{array}$ & & & $\begin{array}{l}\text { Model } 2 \\
\text { (Muslim } \\
\text { immigra }\end{array}$ & & & $\begin{array}{l}\text { Model3 } \\
\text { (Christian } \\
\text { Immigrants) }\end{array}$ & & \\
\hline & $\mathrm{b}$ & $\mathrm{t}$ & $\beta$ & $\mathrm{b}$ & $\mathrm{t}$ & $\beta$ & $\mathrm{b}$ & $\mathrm{t}$ & $\beta$ \\
\hline Constant & 2.52 & $5.41 * * *$ & $\ldots \ldots$ & 3.20 & $7.49 * * *$ & $\ldots \ldots$ & 2.64 & $6.58 * * *$ & $\ldots \ldots$ \\
\hline Party Id & -0.03 & 1.08 & 0.05 & -0.04 & -1.50 & -0.06 & 0.04 & $1.83 *$ & 0.08 \\
\hline Ideological O. & -0.09 & $-2.21 * *$ & -0.09 & -0.13 & $3.58 * * *$ & 0.16 & 0.03 & 0.76 & 0.03 \\
\hline Religion & -0.07 & $-2.50 * *$ & -0.09 & 0.06 & $2.28 * *$ & 0.08 & 0.09 & $3.45 * *$ & 0.13 \\
\hline Age & -0.005 & $-1.75^{*}$ & -0.06 & 0.005 & $1.78^{*}$ & 0.06 & -0.005 & $-1.71^{*}$ & -0.06 \\
\hline Education & 0.14 & $5.07 * * *$ & 0.20 & -0.12 & $-4.76 * * *$ & -0.18 & -0.06 & $-2.53 * *$ & -0.10 \\
\hline Gender & -0.22 & $-2.16^{* *}$ & -0.08 & 0.20 & $2.12 * *$ & 0.08 & 0.09 & 1.05 & 0.04 \\
\hline Income & 0.02 & 1.24 & 0.05 & -0.02 & $-1.88^{*}$ & -0.07 & -0.02 & $-2.17 * *$ & -0.09 \\
\hline
\end{tabular}

Note: N1 = 704; N2 = 704; N3 = 704; R²1 = 0.0831; $\mathrm{R}^{2} 2=0.1017 ; \mathrm{R}^{2} 3=0.0510 ; \mathrm{F} 1=9.01 ; \mathrm{F} 2=11.26 ; \mathrm{F} 3=5.34 ;$ Prob F1 = 0.0000 , Prob F2 = 0.0000, Prob F3 = 0.0000; *** prob. $<0.01 * *$ prob. $<0.05 *$ prob. $<0.10$

Table 3

Main Effects of Education

\begin{tabular}{llllll}
\hline Number of Answer & Control & Treatment 1 & Treatment 2 & Treatment 3 & Total \\
\hline-1 & 9 & 9.36 & 9.5714286 & 9.2083333 & 9.3296703 \\
& 2.8010987 & 2.6595739 & 2.9113898 & 2.2453656 & 2.6249019 \\
& 14 & 25 & 28 & 24 & 91 \\
0 & 8.826087 & 9.8181818 & 8.78125 & 9.3125 & 9.1559633 \\
& 3.5374898 & 2.556716 & 2.7088192 & 2.1766725 & 2.7290424 \\
& 23 & 22 & 32 & 32 & 109 \\
1 & 10.302083 & 10.338462 & 10.373418 & 10.317073 & 10.332335 \\
& 2.0826875 & 2.348131 & 2.319906 & 1.8874785 & 2.1828765 \\
& 192 & 195 & 158 & 123 & 668 \\
2 & 10.018913 & 10.178571 & 10.160606 & 9.8870056 & 10.056133 \\
& 1.9102174 & 1.9799636 & 1.9866484 & 2.179924 & 2.0138999 \\
& 423 & 336 & 330 & 354 & 1443 \\
3 & 9.8136646 & 9.4529412 & 9.9508197 & 10.116183 & 9.8622517 \\
& 1.8748499 & 2.2742754 & 1.8494986 & 1.9458791 & 1.9992287 \\
& 161 & 170 & 183 & 241 & 755 \\
4 & 0.0 & 9.3928571 & 9.8378378 & 9.7575758 & 9.6473214 \\
& 0.0 & 1.8302535 & 1.8507831 & 1.6830431 & 1.7982782 \\
& 0.0 & 84 & 74 & 66 & 224 \\
& 9.9938499 & 9.9543269 & 10.049689 & 9.9642857 & 9.9899696 \\
& 2.0393208 & 2.1846925 & 2.1030694 & 2.048555 & 2.0942137 \\
& 813 & 832 & 805 & 840 & 3290 \\
\hline
\end{tabular}

According to results, attitudes towards general immigration, or about Christian and Muslim immigrants change depending on education level, religion, party identification and ages. Education is effective for all three situations: general opposition to immigration $(t=5.07, p<0.01)$, and opposition to Muslim $(t=-4.76, p<0.01)$ and Christian immigrants $(t=-2.53, \mathrm{p}<0.05)$. Similarly, religion also has an impact for all three situations: 
general opposition to immigration $(t=-2.50, p<0.05)$ and opposition to Muslim $(t=2.28, p<0.05)$ and Christian immigrants $(t=3.45, p<0.05)$.

Table 4

Main Effects of Religion

\begin{tabular}{|c|c|c|c|c|c|}
\hline Number of Answer & Control & Treatment 1 & Treatment 2 & Treatment 3 & Total \\
\hline \multirow[t]{3}{*}{-1} & 6.2857143 & 5.08 & 5.25 & 4.875 & 5.2637363 \\
\hline & 5.5943457 & 4.2614552 & 4.7502437 & 4.7759588 & 4.7089399 \\
\hline & 14 & 25 & 28 & 24 & 91 \\
\hline \multirow[t]{3}{*}{0} & 7.5217391 & 5.3636364 & 7.15625 & 4.8125 & 6.1834862 \\
\hline & 4.8323678 & 4.7863442 & 4.8996996 & 4.3138001 & 4.774867 \\
\hline & 23 & 22 & 32 & 32 & 109 \\
\hline \multirow[t]{3}{*}{1} & 5.4791667 & 6.1589744 & 5.6835443 & 5.6829268 & 5.7634731 \\
\hline & 4.8323678 & 4.7863442 & 4.8996996 & 4.3138001 & 4.774867 \\
\hline & 192 & 195 & 158 & 123 & 668 \\
\hline \multirow[t]{3}{*}{2} & 4.9621749 & 5.3363095 & 5.2484848 & 5.8333333 & 5.3284823 \\
\hline & 4.6274373 & 4.6084144 & 4.8415513 & 4.6892222 & 4.6818782 \\
\hline & 423 & 336 & 330 & 354 & 1443 \\
\hline \multirow[t]{3}{*}{3} & 5.0434783 & 4.9235294 & 5.147541 & 5.5186722 & 5.1933775 \\
\hline & 4.3936713 & 4.4787505 & 4.4715317 & 4.6780364 & 4.5210628 \\
\hline & 161 & 170 & 183 & 241 & 755 \\
\hline \multirow[t]{3}{*}{4} & 0.0 & 4.9761905 & 5.8243243 & 4.9090909 & 5.2366071 \\
\hline & 0.0 & 4.4178613 & 4.8125353 & 4.3278251 & 4.5251959 \\
\hline & 0.0 & 0.0 & 84 & 74 & 66 \\
\hline \multirow[t]{3}{*}{ total } & 5.195572 & 5.4014423 & 5.4397516 & 5.5821429 & 5.406079 \\
\hline & 4.5265914 & 4.5338569 & 4.6139967 & 4.6298421 & 4.5764171 \\
\hline & 813 & 832 & 805 & 840 & 3290 \\
\hline
\end{tabular}

In addition, results show that ideological orientation has an impact on general immigration $(t=-2.21, p<$ $0.05)$ and opposing Muslim immigrants $(t=3.58, p<0.01)$, however, it does not have a significant impact on opposition to Christian immigrants. Income does not have a significant impact on general immigration, but it has a significant negative impact on opposition to Muslim $(t=-1.88, p<0.10)$ and Christian immigrants $(t=$ $-2.17, p<0.05)$.

When looking at the $\beta$ coefficients, the results show that education is relatively the most important factor that influence general opposition to immigration $(\beta=0.20)$ and opposition to Muslim immigrants $(\beta=0.18)$. Religion is the second most important factor for opposition to general immigrants $(\beta=-0.9)$. Thus, the main effects of education and religion for the groups in the experiment are presented in Table 3 and 4.

Then, to test the hypothesis the direct survey questions' answers and list experiment answers are compared. Frequency and percentage of participant responses to direct questions are shown in Table 5.

As discussed above, subtracting the mean and multiplying by 100 provides an unobtrusive estimate of the percentage of respondents opposed to the sensitive item. The mean of control and treatment groups are presented in Table 6. 
Table 5

Direct Questions Answers

\begin{tabular}{llll}
\hline & $\begin{array}{l}\text { General Immigration } \\
\text { Freq./Percentage }\end{array}$ & $\begin{array}{l}\text { Muslim Immigrants } \\
\text { Freq./Percentage }\end{array}$ & $\begin{array}{l}\text { Christian Immigrant } \\
\text { Freq./ Percentage }\end{array}$ \\
\hline Strongly support & $132(16 \%)$ & $145(17 \%)$ & $269(33 \%)$ \\
Somewhat support & $176(22 \%)$ & $147(18 \%)$ & $171(22 \%)$ \\
Neither support nor oppose & $162(20 \%)$ & $300(38 \%)$ & $287(35 \%)$ \\
Somewhat oppose & $173(21 \%)$ & $108(13 \%)$ & $39(4 \%)$ \\
Strongly oppose & $170(21 \%)$ & $113(14 \%)$ & $47(6 \%)$ \\
Total & $813 / 100 \%$ & $813 / 100 \%$ & $813 / 100 \%$ \\
\hline
\end{tabular}

Table 6

Mean and Standard Dev. of Groups

\begin{tabular}{lll}
\hline Groups & Mean & Std. Dev \\
\hline Control Group & 1.853629 & 0.8256821 \\
Treatment 1 & 2.028846 & 1.104257 \\
Treatment 2 & 2.031056 & 1.12426 \\
Treatment 3 & 2.135714 & 1.067746 \\
\hline
\end{tabular}

As a result, the estimates of the percentage of respondents opposed to the sensitive item in the list experiment are calculated. The comparison of direct survey question and list experiment results are presented at Table 7 and Figure 1. In addition, by using an ANOVA analysis, the researcher presents the significant difference between the control groups and treatments groups (see Table 8).

Table 7

Comparison of Direct Survey Question and List Experiment Results

\begin{tabular}{lll}
\hline Opposition & Direct Question & List Experiment \\
\hline Opposition to Cutting of all immigration & $42 \%$ & $28 \%$ \\
Opposition to Muslim immigrants & $27 \%$ & $17 \%$ \\
Opposition to Christian immigrants & $10 \%$ & $18 \%$ \\
\hline
\end{tabular}

Results show that, $42 \%$ of respondents state in the direct survey method that they are opposed cutting off all immigration, however, list experiment estimates that only $28 \%$ is opposed to this policy, supporting the first hypothesis. In other words, people are more likely to oppose immigration, but in direct questions they do not reveal their real thoughts.

When the Muslim and Christian immigrants are compared, it is seen that people are more in favor of granting citizenship to a Christian immigrant compared to a Muslim immigrant. The comparison of direct questions and list experiment shows that people conceal their real thoughts about Muslim immigrants. In direct question 27\% say that they are oppose to granting citizenship to a Muslim immigrant, but list experiment results show that in fact $17 \%$ oppose to granting citizenship to a Muslim immigrant. This supports the second hypothesis of the present study, however, in a different direction providing an interesting finding. This result 
shows that to be against a Muslim immigrant is more socially accepted or it became a kind of social norm to oppose Muslim immigration in public. As a result, when it is asked directly, people automatically say that they are against Muslim immigrants, but in fact, they are neutral or they do not feel that way. Thus, when the list experiment is used, they present their real feelings and thoughts. As a result, $10 \%$ of the people feel under the pressure to say that they are opposed to granting a citizenship to a legal Muslim when it is asked directly versus list experiment. For Christian immigrants, $18 \%$ oppose to granting citizenship to a Christian immigrant in the list experiment versus $10 \%$ in response to the direct survey question. In other words, in the list experiment the number of people who are opposed to Christian immigrant increase, supporting the third hypothesis of the present study.

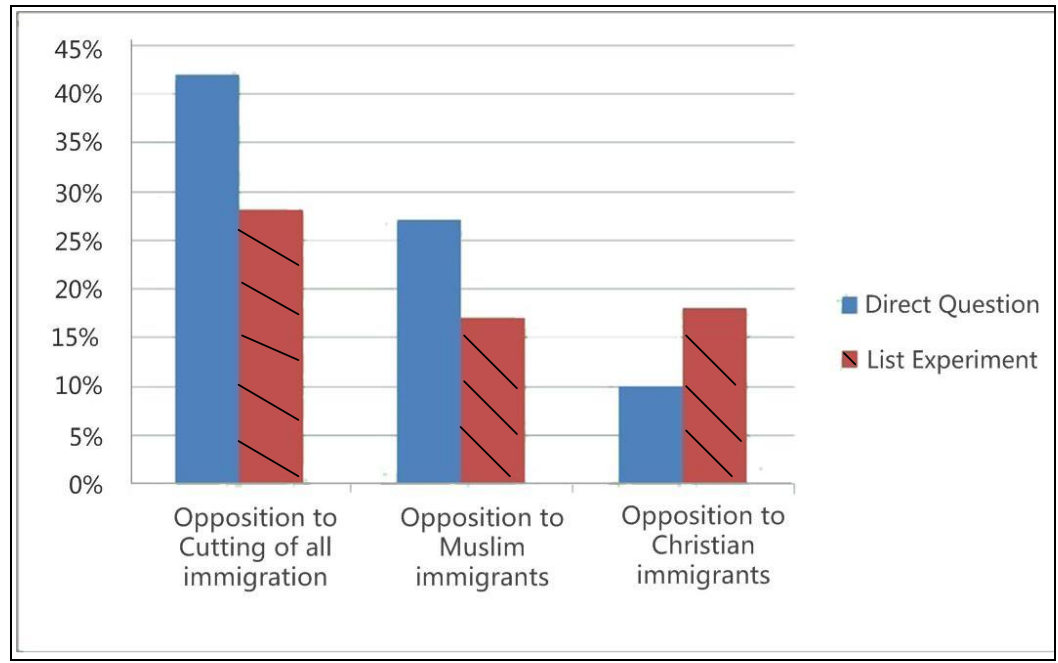

Figure 1. Comparison of direct survey question and list experiment results.

Table 8

Differences of Means for Control and Treatment Group

\begin{tabular}{llllll}
\hline Source & Partial SS & df & MS & F & Prob $>$ F \\
\hline Model & 33.7698881 & 3 & 11.2566294 & 10.45 & 0.0000 \\
Experiment & 33.7698881 & 3 & 11.2566294 & 10.45 & 0.0000 \\
Residual & 3539.64166 & 3286 & 1.07718858 & & \\
Total & 3573.41155 & 3289 & 1.08647356 & & \\
\hline
\end{tabular}

Note. $\mathrm{N}=3290, \mathrm{R}^{2}=0.0095$, Root MSE $=1.03788$, Adj R-squared $=0.0085$.

\section{Discussion and Conclusion}

There is an increasing concern about immigration in the USA. When it is directly asked to people about their feelings on immigration, people are more likely to conceal their real thoughts. This is evident in all three cases (general immigration, feelings about Muslim immigrants, and Christian immigrants) of the present analysis. Specifically, when participants are directly asked about immigration to the USA, they are more likely to argue that they support immigration. For instance, in this study, $42 \%$ of participants state that they oppose to 
cutting off all immigration in a direct question. However, when a list experiment method is used, only $24 \%$ of participants seem to be opposed to cutting off all immigration. In other words, $18 \%$ of participants misrepresent their real feelings about cutting off all immigration.

Moreover, participants are less supportive of Muslim immigrants compared to Christian immigrants. There are some important differences between direct survey questions and list experiment questions as well. When asked directly, $27 \%$ of participants state that they are opposing granting citizenship for a legal immigrant who is Muslim. However, when a list experiment method is used, 17\% of participants are against granting citizenship to a Muslim immigrant. This interestingly shows that to be against Muslim immigration is more socially accepted in public and for that reason people are more likely to state that they oppose Muslim immigrants when it is asked directly. As a result, $10 \%$ of participants probably feel under the pressure to state that they are opposed to granting a citizenship to a legal Muslim.

For Christian immigrants, only $10 \%$ of people say that they are opposed to granting citizenship when asked directly, however, when the list experiment method is used, the results show that $18 \%$ of people are against granting citizenship for a Christian immigrant. In other words, $8 \%$ of people did not actually reveal their real thoughts in the direct survey.

This study shows that social desirability bias is a problem for sensitive issues like immigration, for that reason using a list experiment may be a better methodology for this kind of research. A comparison of direct survey question and list experiment results has the potential to show the social pressure in effect for these sensitive issues. Still, like any other research, there are some limitations in experiment method and the most important one is the sampling bias, because the research is based on only a certain number of people in a certain place. As a result, there are criticisms regarding the generalizability of the results based on a limited sample size (Iyengar, 2009; Humphreys \& Weinstein, 2009). To address this potential limitation, future research can replicate this experiment on different locations, for different countries, and with a larger sample size.

\section{References}

Alibeli, A. M., \& Yaghi, A. (2012). Theories of prejudice and attitudes toward Muslims in the United States. International Journal of Humanities and Social Science, 2(1), 21-29.

American Civil Liberties Union Report. (2013). Retrieved from http://rt.com/usa/aclu-muslims-scrutiny-citizenship-802/

Ayers, J. W. (2007). Changing sides: 9/11 and the American Muslim voter. Review of Religious Research, 49(2), $187-198$.

Barreto, M., Masuoka, N., \& Sanchez. G. (2008). Religiosity, discrimination and group identity among Muslim Americans. Paper Presented at the WPSA Annual Conference, March 2008. California: San Diego.

Barreto, M. A., \& Bozonelos, D. (2009). Democrat, republican or none of the above? The role of religiosity in Muslim American party identification. Politics and Religion, 2, 200-229.

Bauer, T. K., Lofstrom, M., \& Zimmerman, K. F. (2000). Immigration policy, assimilation of immigrants, and natives' sentiments towards immigrants: Evidence from 12 OECD-countries. IZA Discussion Paper.

Burns, P., \& Gimpel, J. (2000). Economic insecurity, prejudicial stereotypes, and public opinion on immigration policy. Political Science Quarterly, 115(3), 201-225.

CAIR. (2006). American public opinion about Islam and Muslims. Retrieved from http://www.cair.com/PDF/cairsurveyanalysis.pdf

Cardwell, D. (2003, June 13). Threats and responses: The immigrants; Muslims face deportation, but say US is their home. The New York Times.

Chandler, C. R., \& Tsai, Y. M. T. (2001). Social factors influencing immigration attitudes: An analysis of data from the general 
social survey. Social Science Journal, 38(2),177-188.

Citrin, J., Green, D. P., Muste, C., \& Wong, C. (1997). Public opinion towards immigration reform: The role of economic motivations. Journal of Politics, 59, 858-881.

CNN.com. (2002). Survey finds Americans distrust of Muslims world. Retrieved June 19, 2011, from http://archives.cnn.com/2002/US/03/04/u.s.muslim.poll/

Creighton, M. (2010). Perceptions of Islam, migration, and citizenship in the United States: A list experiment. TESS (Time Sharing Experiments for the Social Science). Retrieved from http://www.tessexperiments.org/data/creighton022.html

Dustmann, C., \& Preston, I. P. (2006). Is immigration good or bad for the economy? Analysis of attitudinal responses. Research in Labor Economics, 24, 3-34.

Espenshade, T. J., \& Hempstead, K. (1996). Contemporary American attitudes toward US immigration. International Migration Review, 30, 535-570.

Esses, M. V., Dovidio, F. J., \& Hodson, G. (2002). Public Attitudes toward immigration in the United States and Canada in response to the September 11, 2001 "Attack on America”. Analyses of Social Issues and Public Policy, 2, 69-85.

Fetzer, J. S. (2000). Public attitudes toward immigration in the United States, France, and Germany. Cambridge: Cambridge University Press.

Fulton, A. (2002). Survey: Public, leaders veering apart over immigration. Congress Daily.

Gang, I. N., Rivera-Batiz, F. L., \& Yun, M. S. (2002). Economic strain, ethnic concentration and attitudes towards foreigners in the European Union. IZA Discussion Paper.

Hubbard, M. L., Casper, R. A., \& Lessler, J. T. (1989). Respondent reactions to item count lists and randomized response. Proceedings of the Survey Research Section of the American Statistical Association, 544-548.

Humphreys, M., \& Weinstein, J. (2009). Field experiments and the political economy of development. Annual Review of Political Science, 12, 367-378.

Iyengar, S. (2009). Laboratory experiments in political science. Conference on Experimentation in Political Science, Northwestern University.

Janus, A. L. (2007). The list experiment as an unobtrusive measure of attitudes toward immigration. Paper presented at the Social Science Quantitative Methods Working Group at the University of California, Berkeley.

Kalkan, K. O., Layman, G., \& Uslaner, E. M. (2006). American attitudes toward Muslims: Another "other" in US politics. Unpublished typescript.

Kinder, D., \& Sears, D. (1981). Prejudice and politics: Symbolic racism versus racial threats to the good life. Journal of Personality and Social Psychology, 40, 414-431.

Lahav, G. (2004). Immigration and politics in the new Europe. Cambridge: Cambridge University Press.

Latif, Z. (2013, August 14). Islamophobia: Implications on Muslim world. International Relations and Diplomacy, 1(1), 76-81.

McLaren, L. (2003). Anti-immigration prejudice in Europe: Contact, threat perception, and preferences for the exclusion of migrants. Social Forces, 81(3), 909-936.

Mehdi, M. T. (Ed.). (1996). The politics of minority coalitions: Race, ethnicity and shared uncertainties. Westport, CT: Praeger Publishers.

Moore, A. (2010). American Muslim minorities: The new human rights struggle. Retrieved from http://www.du.edu/korbel/hrhw/researchdigest/minority/Muslim.pdf

Naber, N. (2000). Ambiguous insiders: an investigation of Arab American invisibility. Ethnic and Racial Studies, 23(1), 37-61.

Pipes, D., \& Durán, K. (2002). Faces of American Islam: Muslim immigration. Policy Review. Retrieved from http://www.danielpipes.org/441/faces-of-american-islam-muslim-immigration

Public Religion Research Institute. (2011). Survey report: What it means to be American: Attitudes towards increasing diversity in America ten years after $9 / 11$.

Rogers, R. (2012). Christian and Buddhist immigrants coming to America. Retrieved January 6, 2014, from http://www.immigratingtoday.com/2012/04/christian-and-buddhist-immigrants.html

Schaeffer, R. T. (2006). Racial and ethnic groups (10th ed.). Upper Saddle River, New Jersey: Pearson.

Sears, D., \& Funk. C. (1990). The limited effect of economic self-interest on the political attitudes of the as public. Journal of Behavioral Economics, 19, 247-271.

Sears, D., Lau, R., Tyler, T., \& Allen, H. (1980). Self interest vs. symbolic politics in policy attitudes and presidential voting. American Political Science Review, 74, 670-684.

Smith, T. (2006). The root causes of immigration. CCK Hispanic Committee. 
Spector, P. (2004). Social desirability bias. In M. Lewis-Beck, A. Bryman, \& T. Liao (Eds.), Encyclopedia of social science research methods (pp. 1045-1046). Thousand Oaks, CA: Sage Publications.

The New Immigrant Survey. (2003). Retrieved from http://nis.princeton.edu/key_findings.html

The Pew Research Center. (2006). Survey report: America's immigration quandary report. Retrieved from http://www.pewresearch.org/

The Pew Research Center. (2007). Survey report: Muslim Americans, middle class and mostly mainstream. Retrieved May 2 , 2014, from http://www.pewresearch.org/2007/05/22/muslim-americans-middle-class-and-mostly-mainstream/

The Pew Research Center. (2012). Survey report: Faith on the move: The religious affiliation of international migrants report. Retrieved from http://www.pewresearch.org/

The Pew Research Center. (2013). Survey report: Changing patterns of global migration and remittances. Retrieved May 2, 2014, from http://www.pewsocialtrends.org/2013/12/17/changing-patterns-of-global-migration-and-remittances/

Warner, S. (2004). Immigrants and faith they bring. Retrieved January 4, 2014, from http://www.religion online.org/showarticle.asp?title $=2946$

White, J. (2010). Macho Islam. Retrieved February 5, 2014, from http://kamilpasha.com/?p=3780

Xhaho, A. (2014). General discourses on relating honor crimes to Islam and Muslim world: Implications of cultural relativism and essentialist approach. International Relations and Diplomacy, 2(6), 380-388.

Zigerell, L. J. (2011). You wouldn't like me when I'm angry: List experiment misreporting. Social Science Quarterly, 92(2), 552-562. 